\title{
Integrated urban flood risk assessment - adapting a multicriteria approach to a city
}

\author{
C. Kubal ${ }^{1}$, D. Haase ${ }^{2}$, V. Meyer ${ }^{3}$, and S. Scheuer ${ }^{4}$ \\ ${ }^{1}$ Helmholtz Centre for Environmental Research - UFZ, Department of Computational Landscape Ecology, \\ Bernhard-Göring-Straße 110, 04275 Leipzig, Germany \\ ${ }^{2}$ Helmholtz Centre for Environmental Research - UFZ, Department of Computational Landscape Ecology, \\ Permoserstr. 15, 04318 Leipzig, Germany \\ ${ }^{3}$ Helmholtz Centre for Environmental Research - UFZ, Department of Economics, Permoserstr. 15, \\ 04318 Leipzig, Germany \\ ${ }^{4}$ Martin-Luther-University Halle-Wittenberg, Department of Geosciences, Von-Seeckendorf-Platz 4, \\ 06120 Halle/Saale, Germany
}

Received: 14 August 2009 - Revised: 29 October 2009 - Accepted: 31 October 2009 - Published: 17 November 2009

\begin{abstract}
Flood risk assessment is an essential part of flood risk management. As part of the new EU flood directive it is becoming increasingly more popular in European flood policy. Particularly cities with a high concentration of people and goods are vulnerable to floods. This paper introduces the adaptation of a novel method of multicriteria flood risk assessment, that was recently developed for the more rural Mulde river basin, to a city. The study site is Leipzig, Germany. The "urban" approach includes a specific urbantype set of economic, social and ecological flood risk criteria, which focus on urban issues: population and vulnerable groups, differentiated residential land use classes, areas with social and health care but also ecological indicators such as recreational urban green spaces. These criteria are integrated using a "multicriteria decision rule" based on an additive weighting procedure which is implemented into the software tool FloodCalc urban. Based on different weighting sets we provide evidence of where the most flood-prone areas are located in a city. Furthermore, we can show that with an increasing inundation extent it is both the social and the economic risks that strongly increase.
\end{abstract}

\section{Introduction}

Floods belong to the most threatening natural hazards for humans, their lives and their property (Blaikie et al., 1994; WBGU, 1999). The number of floods and the damage resulting from them over recent decades all over the world obviously require an ongoing improvement of analysis, mitiga-

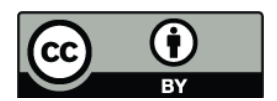

Correspondence to: D. Haase (dagmar.haase@ufz.de) tion and management (Kundzewicz and Kaczmarek, 2000; Ebert et al., 2009). Urban areas in particular suffer from a comparatively high flood risk due to their high population number and density, multiple economic activities and lots of infrastructure and property values (Pelling, 2003). In addition to population growth and the ongoing accumulation of value assets, both the frequency and magnitude of river floods due to climate change are expected to increase in the future, therefore aggravating the existing flood risk (Milly et al., 2002).

Within flood research it has been widely accepted that absolute flood protection can not be achieved (Schanze, 2006). Instead, growing attention has been given to the new paradigm of flood risk management based on the effective establishment of both risk mitigation (structural technical flood defense measures such as dams, dikes or polders) and adaptation (non-structural, "soft" measures such as preparation of the local people, flood insurances, information management, social networks) measures (Krysanova et al., 2008). The concept of flood risk management does not only encompass the hazard event as such but also its possible consequences. The need for a better risk management has also been emphasised by the EU: The new Flood Directive (2007/60/EC) aims at establishing a framework for the assessment and mapping of flood risk in Europe.

Therefore, flood risk maps need to be created as they provide a basis for the development of flood risk management plans (Moel et al., 2009). What is more, these plans need to be effectively communicated to various target groups (including decision makers, emergency response units and the public) as a measure to reduce flood risk by integrating different interests, potential and conflicts over space and land use in a city.

Published by Copernicus Publications on behalf of the European Geosciences Union. 
In urban areas, a proper flood risk assessment is still challenging because it is even more multi-facetted than in rural areas: Common flood risk analyses do not usually incorporate social and ecological impacts but exclusively assess economic damages, which can be measured in monetary terms (Haque and Etkin, 2007). Comprehensive approaches which try to integrate economic, ecological and social impacts are less available (Schanze, 2006). Particularly the latter are frequently omitted due to a lack of suitable data (as argued in Ebert et al., 2009). Urban flood risk assessment requires detailed knowledge about the risk in respective parts of a town to be effective and of use for urban planning and hazard management.

In our study, the flood risk $R$ is defined as a combination of the recurrence probability $P$ of a damaging flood event (= flood hazard) and a number of potential negative consequences $C_{n}$ in a given area (Gouldby and Samuels, 2005; Schanze, 2006; Eq. 1):

$R=P \cdot C_{n}$

In other words, risk is defined here as the expected annual average damage of flooding, where "damage" covers economic as well as social and environmental negative consequences. The application of such a multicriteria assessment of flood risk is relatively rare. Some approaches e.g. King (2001), Fekete (2009), or Kaplan et al. (2009) gather vulnerability indicators or develop integrated vulnerability indices for different kinds of natural hazards, with an emphasis on social vulnerability indicators. Spatial multicriteria approaches for flood risk management are developed by Tkach and Simonovic (1997), Simonovic and Nirupama (2005), and Thinh and Vogel (2006). However these approaches focus on the evaluation of flood mitigation measures instead of flood risk assessment and mapping. Meyer et al. (2009a, b) developed a multicriteria flood risk assessment and mapping approach which covers the three dimensions of risk, namely economic, social and ecological risk. The approach represents a new method for assessing the flood risk for larger landscapes in an integrated way; it was applied for the River Mulde in Saxony, Germany. At the crux of the multicriteria approach is a database comprising economic, social and ecological risk criteria and the software FloodCalc, which enables a spatially explicit and weighted risk calculation.

In our "urban" study we apply the multicriteria approach developed by Meyer et al. (2009a, b) to the city of Leipzig. The study site is highly suitable for this kind of study since it is (1) situated on a river and has already experienced floods on numerous occasions, (2) is predicted to be faced with an increase in precipitation due to climate change in the near future (Bronstert, 1996; Enke and Küchler, 2000) which also make floods more probable, and (3) provides a very good digital database for the adaptation of the procedure by Meyer et al. (2009a, b). In this context, the following re- search questions are addressed:

- Which criteria of risk should be considered for an urban integrated flood risk assessment?

- How do differently weighted criteria sets alter both the value and spatial distribution of the multicriteria flood risk in a city?

- What are the potential and limitations of adapting an approach which was originally developed for a river basin to a city?

The paper is structured as follows: after introducing the background and the aim of the study in Sect. 1, the study area is presented in Sect. 2. Section 3 expands on the multicriteria urban flood risk mapping approach and specifies the adaptations made to the procedure according to Meyer et al. (2009a) for a city. The results are discussed in Sect. 4 before coming to some conclusions in Sect. 5 .

\section{Study area}

The city of Leipzig is situated in the eastern part of Germany, $51.3^{\circ} \mathrm{N}$ and $12.4^{\circ} \mathrm{W}$, has about 515000 inhabitants and covers a total area of $300 \mathrm{~km}^{2}$ (Fig. 1). The mean annual precipitation reaches $650 \mathrm{~mm}$; the average annual mean temperature is $9^{\circ} \mathrm{C}$. Leipzig is situated in the Central German lowlands; the main topographical features are represented by the Holocene floodplains which are embedded in the Pleistocene plateaus (Neumeister et al., 1997). Leipzig is situated along the rivers of the Weiße Elster, Pleiße and Parthe which converge in the city area. The city is situated to the north of the hilly Weiße Elster catchment and thus exposed to floods which originate from the southern Vogtland mountains. The river system of Leipzig is characterised by a high variability in water discharges among the different rivers and over the year. Due to the pluvial rainfall system, flood situations are typical during the snow melting period of early spring and late summer/autumn (Neumeister et al., 1997).

Leipzig is a compact city with a dense old built-up residential core and high land use value assets. Overall it has $63 \mathrm{mu}-$ nicipal districts. The town centre is situated close to floodplains. It is also in flood-prone areas that most of the oldindustrial developments of the late 19th and early 20th centuries and recent urban renewal activities have taken place. Land use changes due to residential and industrial development over the last century (Wilhelminian Period) were accompanied by a straightening of the rivers and a loss of natural flooding area which in turn increased the urban flood risk and the respective damage potential considerably (cf. Davidson, 2006). The last severe flood hazard in the the city of Leipzig occurred in July 1954 when large parts of the inner city were flooded resulting in a lot of economic damages; the last minor flood event was in 2002, the year of the big "Elbeflood" in Germany. 


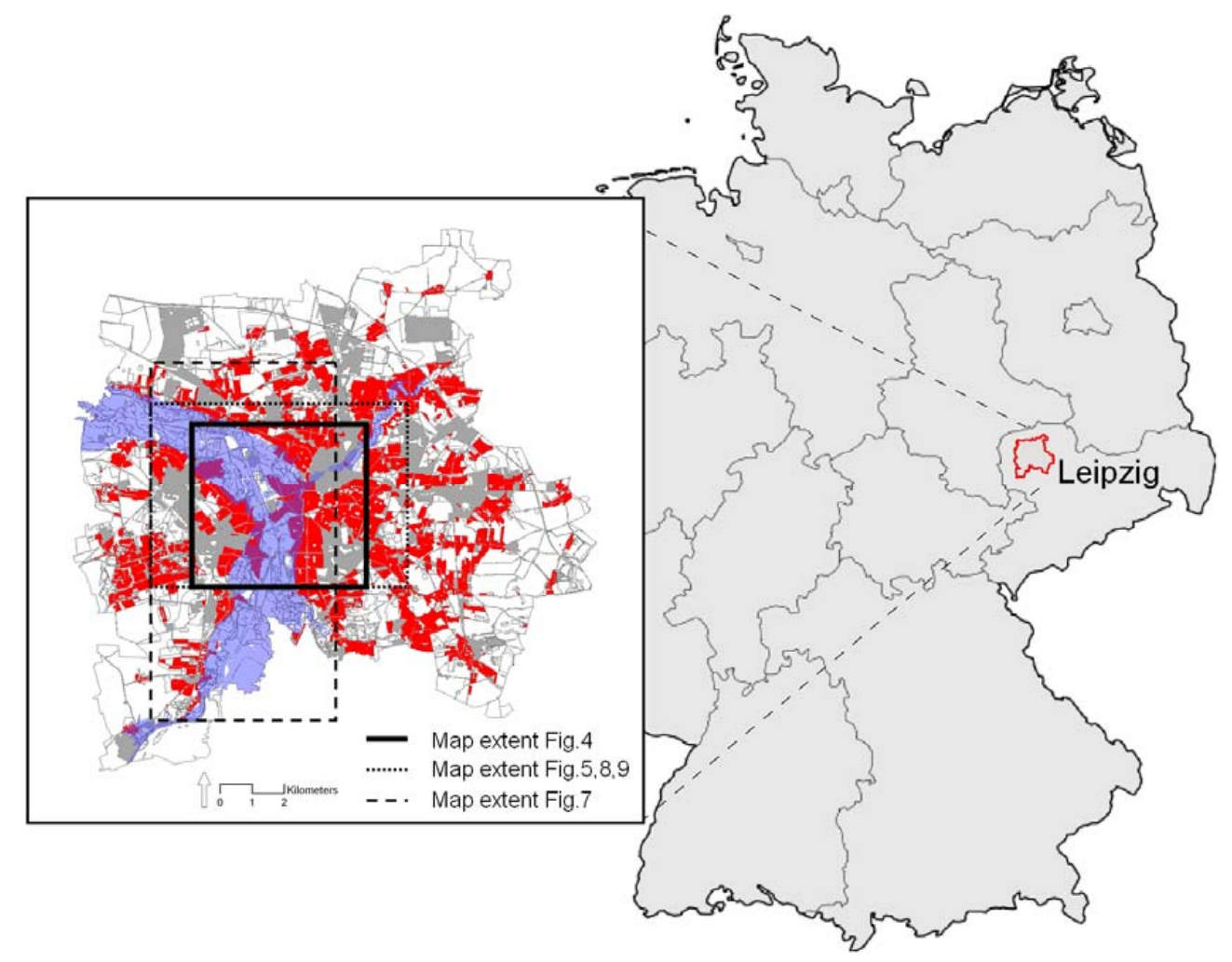

Fig. 1. Study area of the city of Leipzig in Saxony, Germany: river network (dark blue), inundation area calculated for a 100-year recurrence probability (light blue) and urban fabric (red).

Recently the city has been experiencing an increase in oneperson households, mainly in the inner, hazard-prone part of the town. Moreover, Leipzig faces a considerable ageing of the population (City of Leipzig, 2008).

\section{Integrated urban flood risk assessment}

The methodological background of our study is a multicriteria approach for flood risk assessment and mapping developed by Meyer et al. (2009a, b). It covers the three dimensions of vulnerability - social, economic and ecological (Fig. 2). It was developed for larger parts of a river basin and tested for the Mulde river in Germany for which it produced convincing sets of differently weighted risk criteria. The multicriteria assessment tool by Meyer et al. (2009a, b) is based on a set of publicly available data that have been put together in a Geographical Information Systems (GIS) and processed using the software FloodCalc. The results can be re-imported into a GIS to produce user-defined and specific flood risk maps. This makes the procedure attractive for urban flood risk and hazard management. The general procedure of this multicriteria risk mapping approach is the following: Based on inundation depth data for flood events with a different exceedence probability of discharge and information on the spatial distribution of elements at risk for the different criteria absolute damages or affected units, respectively, are calculated for these different flood events. Based on these different damage figures and their associated probabilities the expected annual average damage or flood impact is calculated according to Eq. (1). Each of the different criteria risk maps is then standardised to values between 0 and 1 , weighted and finally aggregated to a multicriteria risk map. All these calculations are carried out for grid with a spatial resolution of $10 \mathrm{~m}$. In the Mulde case study (ebd.) only relatively few risk criteria were used: As economic risk criterion the annual average direct damage, as ecological risk criteria the erosion and accumulation potential of pollutants, as well as the probability of vulnerable biotopes of being affected, and as social risk criteria the annual affected population and the probabilities of vulnerable community locations (schools, hospitals etc.) of being affected.

In order to apply this method to an urban region several steps of adaptation are necessary. Cities are very complex in terms of their potential flood risk due to high population densities, diverse land use patterns including a variety of residential land use types as well as a great density of economic asset values. The flood risk criteria used by Meyer et al. (2009a, b) therefore had to be extended and modified: arable and forest land uses were replaced by settlement and commercial land use types. In addition, urban land use often forms very heterogeneous patterns which require a high grain for the 


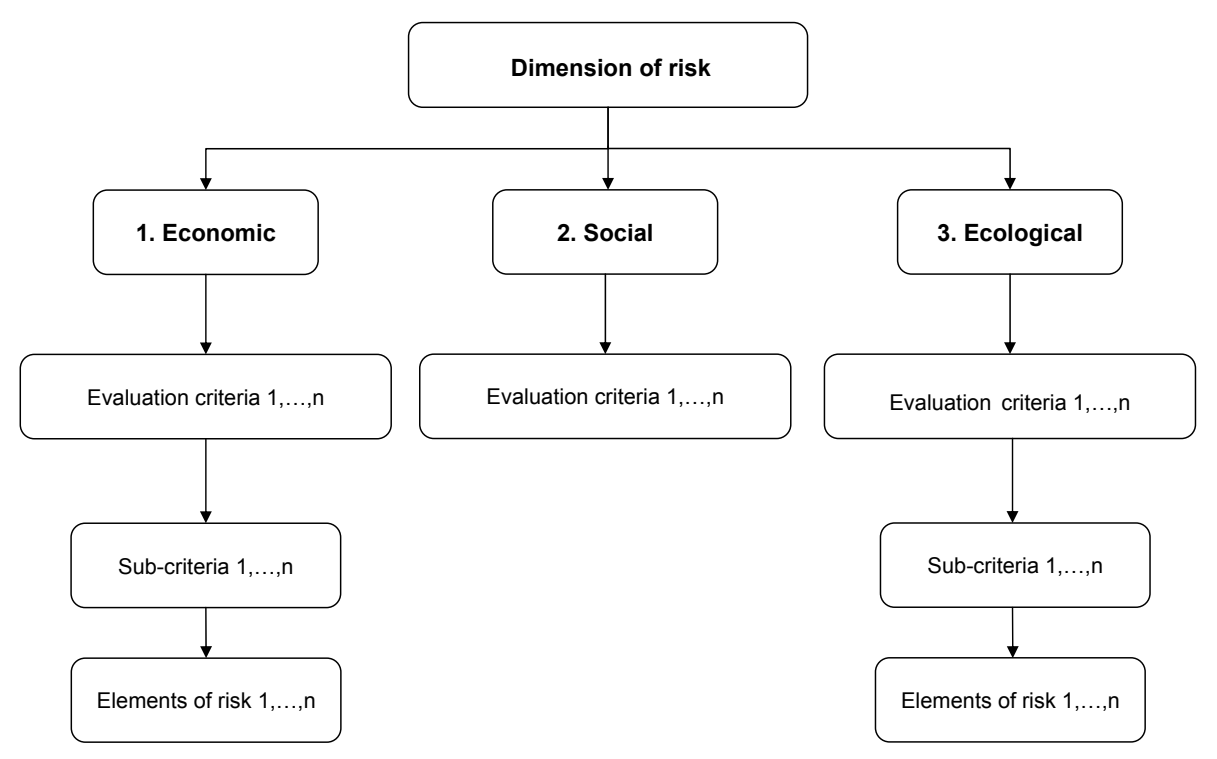

Fig. 2. Criteria hierarchy to measure the urban flood risk.

analysis and the respective input data. For many urban land use types and socio-demographic data no inundation-depthdamage-function exists. Therefore, for most of the criteria introduced in the following, the calculation of the potential damage was computed using a binary approach "flooded or non-flooded". In the following sub-sections the selection of the flood risk criteria and elements of risk will be explored in more detail.

\subsection{Urban flood risk criteria}

\subsubsection{Selection}

The selection of risk criteria is an essential part of each multicriteria approach. Compared to many other existing flood risk analyses which usually focus on the estimation or measurement of the economic damage exclusively (Brouwer and Ek, 2004; Meyer et al., 2008), in our study, elements of risk from different sectors are used. As an element of risk we understand the spatial entity at which the risk measures work, in our case $10 \times 10 \mathrm{~m}$ cells. One element of risk encloses a specific number of population and houses, a land value, a proportion of recreation area, etc. An overview about the elements of risk is given in Table 1.

We used a hierarchical procedure to carefully elicit the different elements of risk and to cover all three dimensions of vulnerability as equally as possible: firstly flood risk criteria were assigned to each dimension. Some of these were further classified into sub-criteria. The final elements of risk are those that will be quantified (Fig. 2). Thus, for them a spatial unit was given that reports how this element of risk is spatially represented in the GIS map. In addition, the damage unit gives information about whether the respective data set enters an inundation-depth-damage-calculation or is handled as binary information for the estimation of damage.

\subsubsection{Data compilation and preparation}

All data used for our analysis is publicly available and upto-date. We obtained most of the data from municipal statistics (census and social data of the City of Leipzig for 2006 and 2007) or urban planning agencies (land values). Land use data were compiled using the German Topographic Information System (ATKIS, 2006) 1:25000 and additional highgrain topographic maps $(1: 10000)$ which were digitised onscreen. The number and type of land use classes chosen in our analysis correspond to the spatial scale of preparatory land use plans used in urban planning. Social data in form of statistical time series available for each municipal district in the city's annual census were disaggregated to the houses of the residential land use cover in order to exactly determine where people live (cf. also Maantay and Maroko, 2009). Ecological criteria were either derived directly from the land use information or taken from the urban tree cadaster database (2006). For the analysis, all elements at risk were converted into a raster format using ArcGIS 9.3 with a grid cell size of $10 \times 10 \mathrm{~m}$.

\section{Economic risk}

The economic flood risk is characterised by two criteria: firstly, the aggregated economic risk is based on six single land use-type elements of risk - that is transport, residential buildings, industrial and commercial areas, administration and service, sport and recreation and garden allotments (Table 1). Residential houses and industrial and commercial 
Table 1. Flood risk criteria including the three dimensions of vulnerability (specific additional "urban" criteria or "urban high grain scale" compared to FloodCalc in italics).

\begin{tabular}{|c|c|c|c|c|c|c|}
\hline $\begin{array}{l}\text { Flood } \\
\text { risk } \\
\text { dimension }\end{array}$ & $\begin{array}{l}\text { Evaluation } \\
\text { criteria }\end{array}$ & Sub-criteria & Elements of risk & $\begin{array}{l}\text { Spatial unit } \\
\text { (in GIS) }\end{array}$ & $\begin{array}{l}\text { Damage unit } \\
{[\ldots / \text { Year }]}\end{array}$ & $\begin{array}{l}\text { Spatial } \\
\text { scale* }^{*}\end{array}$ \\
\hline \multirow{6}{*}{$\sum_{\substack{U \\
ٍ}}$} & \multirow{5}{*}{ 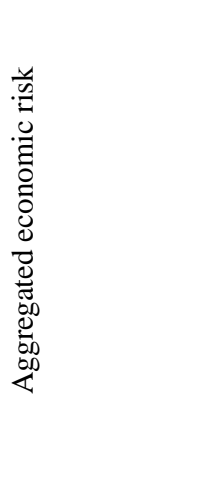 } & Transport & Streets, railways & Line & binary & microscale \\
\hline & & Housing & Residential buildings & Area & binary & microscale \\
\hline & & Commerce & $\begin{array}{l}\text { Industrial buildings } \\
\text { and commercial sites }\end{array}$ & Area & binary & microscale \\
\hline & & Administration & $\begin{array}{l}\text { Administration and } \\
\text { service, fairground, } \\
\text { technical supply } \\
\text { and dispersal }\end{array}$ & Area & binary & mesoscale \\
\hline & & Recreation & $\begin{array}{l}\text { Garden allotments } \\
\text { Sport and recreation } \\
\text { facilities }\end{array}$ & Area & binary & mesoscale \\
\hline & Land value & & Land value per floor space & Area & Euros & mesoscale \\
\hline \multirow{4}{*}{ 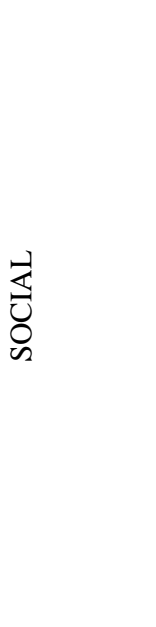 } & Population & & $\begin{array}{l}\text { Affected population } \\
\text { per residential } \\
\text { building (excluding } \\
\text { children and } \\
\text { elderly people) }\end{array}$ & Area & $\begin{array}{l}\text { Number } \\
\text { of } \\
\text { people }\end{array}$ & microscale \\
\hline & Children & & $\begin{array}{l}\text { Affected children per } \\
\text { residential house } \\
(0-10 \text { years })\end{array}$ & Area & $\begin{array}{l}\text { Number } \\
\text { of } \\
\text { people }\end{array}$ & microscale \\
\hline & Elderly people & & $\begin{array}{l}\text { Affected elderly per } \\
\text { residential home } \\
\text { (>65 years) }\end{array}$ & Area & $\begin{array}{l}\text { Number } \\
\text { of } \\
\text { people }\end{array}$ & microscale \\
\hline & Social hot spots & & $\begin{array}{l}\text { Social infrastructure } \\
\text { such as schools, } \\
\text { kindergartens, hospitals, } \\
\text { pensioners' homes, etc. }\end{array}$ & Point & binary & microscale \\
\hline \multirow{5}{*}{ 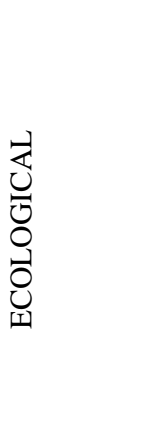 } & \multirow{5}{*}{ 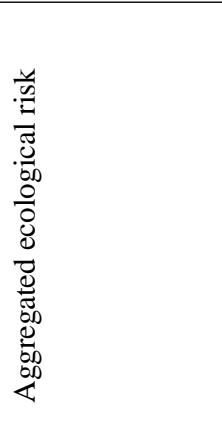 } & Potential pollution & Contaminated sites & Point & binary & microscale \\
\hline & & Erodibility & $\begin{array}{l}\text { Non-sealed surfaces } \\
\text { with erosion potential }\end{array}$ & Area & binary & microscale \\
\hline & & Trophic level & Peat bogs, heath etc. & Area & binary & microscale \\
\hline & & Biodiversity & $\begin{array}{l}\text { Semi-arid grasslands, } \\
\text { poor marsh areas, etc. }\end{array}$ & Area & binary & microscale \\
\hline & & Forest & $\begin{array}{l}\text { Forest areas with } \\
\text { a proportion of tree } \\
\text { species sensitive to } \\
\text { inundation }>20 \%\end{array}$ & Area & binary & microscale \\
\hline
\end{tabular}

* according to Steinhardt and Volk (2002). 
Table 2. Classification of the building heights that were used to calculate the number of people living in a residential house and of industrial and commercial buildings.

\begin{tabular}{lc}
\hline & Number of floors \\
\hline $\begin{array}{l}\text { Residential buildings } \\
\text { Wilhelminian-style 19th century buildings, } \\
\text { tenement blocks }\end{array}$ & $4 \ldots 5$ \\
$\begin{array}{l}\text { Town Centre } \\
\text { Prefabricated multi-storey houses } \\
\text { from the socialist period of the city }\end{array}$ & $3 \ldots 5$ \\
$\begin{array}{l}\text { Detached and semi-detached houses, } \\
\text { urban villas }\end{array}$ & $6 \ldots 9$ \\
$\begin{array}{l}\text { Terraced houses } \\
\text { Council houses }\end{array}$ & 2 \\
$\begin{array}{l}\text { Industrial and commercial buildings } \\
\text { Pre-WWII-buildings }\end{array}$ & 8 \\
Post-reunification (1990ff) buildings & $3 \ldots 5$ \\
\hline
\end{tabular}

buildings entered the analysis as single vectors considering the number and height of each building defined as given in Table 2. This avoids under- or overestimating vulnerable groups and sub-populations with regard to their flood risk as argued by Maantay and Maroko (2009). Areas of administration, service, sport and recreation were selected from the land use map.

Secondly, the criterion of the land values was calculated by intersecting the vector map of the buildings and a landvalue map with information on the municipal district level. The land value can be used as a proxy to estimate the financial loss of assets in the city since more detailed information is often hardly available and, what is more, often varies in space and time (Filatova et al., 2009). Land prices in cities strongly depend on spatial location along the urban-to-rural gradient; particularly in town centres and preferential residential estates land prices are extremely high (Schätzl, 2003).

\section{Social risk}

Recent literature on natural hazards highlights the significance of the social dimension in hazard and related risk analysis (Haque and Etkin, 2007). Regarding the high density of a population in cities, a proper small-scale (high grain) measurement of potentially endangered inhabitants is crucial. However there is still much uncertainty about the specific social criterion that accounts for urban vulnerability. In our case, the following criteria were considered as tremendously important for being part of our integrated urban criteria set: the affected (total) population (excluding children and the elderly), the number of children, the number of elderly people, and the number of social hot spots (cf. also King and MacGregor, 2000).
Humans are the most important value in flood protection. Next to direct physical harm, humans may suffer damage from extreme floods due to psychic trauma, stress and contaminated drinking water (Gruenwald, 2001; Tapsell et al., 2002). Elderly people and children represent age classes which are particularly vulnerable to floods (Meyer et al., 2009a) as they depend on support in case of a flood event. Moreover, flood damage to nursing homes, kindergartens and schools poses unexpected financial discomforts for parents, relatives and the staff. Furthermore, elderly people are at risk again due to their lower constitutional mobility (Cutter et al., 2003).

The criteria of the affected population, children, and elderly people are quantified by means of a micro-scale approach: census data at municipality district level were taken and downscaled to single houses and their number of levels (Table 2). The corresponding residential land use units compile all buildings with an exact number of potentially affected people in an accumulated form. To do so, the assumption was made that all buildings of one land use type have the same number of floors, respectively (cf. again Table 2). The proportion of children and elderly people was proportionally assigned.

Places with social and health care and related infrastructure facilities play an important role in ensuring the quality of life of the urban population. Thus, damages caused by flood events could lead to substantial losses of such infrastructure. In order to capture such damage potential the following infrastructure facilities were considered: schools, kindergartens, pensioners' homes, fire stations, and hospitals.

\section{Ecological risk}

Besides economic and social damages, floods may also influence the environment and thus reduce or even enhance biodiversity and ecosystem functionality (Apel et al., 2004; US EPA, 1992). Moreover, Krüger et al. (2005) were able to demonstrate with the Elbe in 2002 that floods can redistribute existing soil pollutants, particularly in urban areas. In order to assess the ecological flood risk, it is represented by the following elements: potential contamination, soil erodibility, abundance of oligotrophic biotopes, vulnerable protected biotopes, and vulnerable trees with low withstanding against long-term inundation. The latter is important for urban forest management because the floodplain forests of Leipzig and their adjacent parks consist to a large extent of tree species like ash (Fraxinus excelsior) and marple (Acer platanoides) which start to die-off after a 5 day inundation (Hauschild and Hein, 2008).

\subsection{Binary standard of evaluation}

Most of the 16 chosen elements of risk listed in Table 1 are allocated in the case study area by use of a binary code which 
means that damage is calculated using simple Boolean 0 and 1 (false and true) values. Hence, the presence or absence of an element of risk in the inundation area reduces or respectively increases the flood risk, irrespective of inundation depth.

Although an overall higher uncertainty of Boolean values this kind of approach has a number of advantages of such a binary value system: Criteria and elements of risk can be located easily without the need to be measured in monetary, social or ecological sensitivity terms. Therefore, the assessment of multiple criteria quantifying potential damages and risks is a big advantage, particularly when this concerns a complex system such as a city. Hence, the way the set of criteria is composed is very flexible because additional criteria may be easily and quickly integrated into the analysis. Furthermore, the method that has been developed can be easily comprehended by scientists from different disciplines and non-scientists alike, urban planners, water or hazard managers, which is particularly important in the decision-making process. Only the criteria of affected population, children, elderly people, and as mentioned before, land values, are not calculated by means of a Boolean damage function.

\subsection{Scale}

According to the objectives of a flood risk study, the case study area, the budget and the time available, the scale of the analysis of the respective risk assessment has to be chosen. The scale strongly influences the results of a risk assessment study and therefore needs to be defined (Meyer, 2005). The multi-criteria approach by Meyer et al. (2009a, b) was developed for a larger section of the River Mulde for which damage and risks are assessed using a meso-scale approach. In contrast, the present study uses a micro-scale approach to compute and allocate flood risk. Except for the criteria of administration and service, sport and recreation, or allotment gardens, all other economic and social criteria were quantified for individual house levels and flats.

\subsection{Risk calculation and weighting using FloodCalc Urban}

The general procedure of the urban flood risk assessment is shown in Fig. 3. The computation of the weighted aggregated multicriteria flood risk as such was realised using the software FloodCalc Urban, a modification of the FloodCalc software package that has already been published (Meyer et al., 2009a). New damage functions and criteria were incorporated into the software. Moreover, the software performance was enhanced in that FloodCalc Urban can handle a larger number of cells than FloodCalc which is necessary to depict the much more heterogeneous land use pattern of a city. The better performace results from partial code refactoring, which allows a more efficient use of computational resources, with the available memory being the limiting fac-

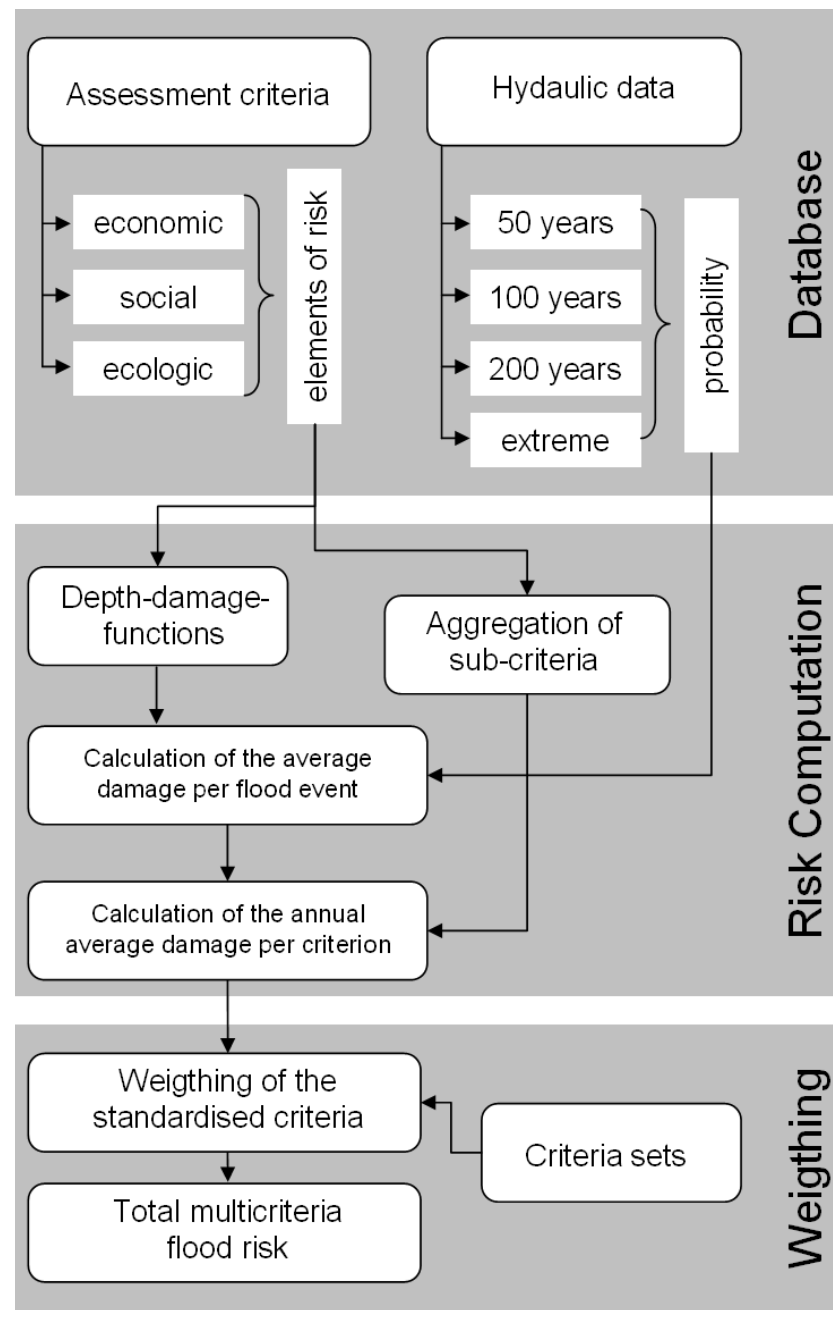

Fig. 3. Step-wise procedure of the multicriteria flood risk mapping approach implemented in FloodCalc Urban.

tor. The original version of FloodCalc can handle about 4.2 million grid cells per input raster and criterion on a typical office computer equipped with 1 GB RAM (Meyer et al., 2009a). FloodCalc Urban is capable to handle about 50\% larger input files, giving a total number of about 6.5 million grid cells per input raster and criterion ${ }^{1}$. The results are presented in the form of risk maps.

To calculate the depth of inundation we used the data from four flood events with different recurrence probabilities provided by the Saxon Water and Flood Management Authority $(1 / 50=$ recurrence probability in 50 years, $1 / 100,1 / 200$, 1/500). Additionally, we used maps with information of the spatial distribution of the elements of risk discussed above.

\footnotetext{
${ }^{1}$ FloodCalc 2, which is currently under development, will handle much larger grid files, as the code is completely rewritten and optimized.
} 
Table 3. Weights (in \%; cf. Sect. 3.4) of the social, economic and ecological criteria for all criteria sets applied.

\begin{tabular}{|c|c|c|c|c|c|c|c|c|}
\hline \multirow{2}{*}{$\begin{array}{l}\text { Flood } \\
\text { vulnerability } \\
\text { dimension } \\
\text { Evaluation } \\
\text { criteria }\end{array}$} & & \multicolumn{2}{|c|}{$\begin{array}{c}1 . \\
\text { ECONOMIC }\end{array}$} & \multicolumn{4}{|c|}{$\begin{array}{c}2 . \\
\text { SOCIAL }\end{array}$} & \multirow{2}{*}{$\begin{array}{c}3 . \\
\text { ECOLOGICAL } \\
\\
\text { Aggregated } \\
\text { ecological } \\
\text { risk }\end{array}$} \\
\hline & & $\begin{array}{l}\text { Aggregated } \\
\text { economic } \\
\text { risk }\end{array}$ & $\begin{array}{l}\text { Land } \\
\text { value }\end{array}$ & Population & Children & $\begin{array}{l}\text { Senior } \\
\text { citizens }\end{array}$ & $\begin{array}{c}\text { Social } \\
\text { hot-spots }\end{array}$ & \\
\hline \multirow{8}{*}{ Criteria set } & EQUAL & $\begin{array}{r}16.7 \\
33.3\end{array}$ & 16.7 & 8.3 & $\begin{array}{l}8.3 \\
\quad 33.3\end{array}$ & 8.3 & 8.3 & $\begin{array}{l}33.3 \\
33.3\end{array}$ \\
\hline & ECON & $\begin{array}{l}30.0 \\
\quad 60.0\end{array}$ & 30.0 & 5.0 & $\begin{array}{l}5.0 \\
20.0\end{array}$ & 5.0 & 5.0 & $\begin{array}{l}20.0 \\
20.0\end{array}$ \\
\hline & SOCIAL & $\begin{array}{l}10.0 \\
20.0\end{array}$ & 10.0 & 15.0 & $\begin{array}{l}15.0 \\
60.0\end{array}$ & 15.0 & 15.0 & $\begin{array}{l}20.0 \\
20.0\end{array}$ \\
\hline & ECOL & $\begin{array}{l}10.0 \\
20.0\end{array}$ & 10.0 & 5.0 & $\begin{array}{l}5.0 \\
20.0\end{array}$ & 5.0 & 5.0 & $\begin{array}{l}60.0 \\
60.0\end{array}$ \\
\hline & SPOTS & $\begin{array}{l}2.5 \\
\\
\end{array} .0$ & 2.5 & 5.0 & $\begin{array}{l}5.0 \\
90.0\end{array}$ & 5.0 & 75.0 & $\begin{array}{l}5.0 \\
5.0\end{array}$ \\
\hline & COHORTS & $\begin{array}{l}2.5 \\
5.0\end{array}$ & 2.5 & 5.0 & $\begin{array}{l}40.0 \\
\quad 90.0\end{array}$ & 40.0 & 5.0 & $\begin{array}{l}5.0 \\
5.0\end{array}$ \\
\hline & $\begin{array}{l}\text { ECON } \\
\text { extreme }\end{array}$ & $\begin{array}{l}45.0 \\
\quad 90.0\end{array}$ & 45.0 & 1.25 & $\begin{array}{l}1.25 \\
\\
\end{array}$ & 1.25 & 1.25 & $\begin{array}{l}5.0 \\
5.0\end{array}$ \\
\hline & $\begin{array}{l}\text { ECOL } \\
\text { extreme }\end{array}$ & $\begin{array}{l}2.5 \\
5.0\end{array}$ & 2.5 & 1.25 & $\begin{array}{l}1.25 \\
\\
\end{array} .0$ & 1.25 & 1.25 & $\begin{array}{l}90.0 \\
90.0\end{array}$ \\
\hline
\end{tabular}

Damages were calculated by intersecting maps of the different elements of risk with the inundation maps. Since various sub-criteria may occur simultaneously during one flood event and therefore accumulate, binary-coded sub-criteria are added to the aggregated economic risk and aggregated ecological risk, which are then used further in the multicriteria procedure. For all non-binary criteria, a depth-damagefunction is applied to calculate the degree of damage from each element of risk. The damage function (Eq. 2) is taken from the HOWAS-database, the biggest database on flood damages in Germany. Although derived only from residential flood damage figures, we apply this formula for all nonbinary criteria. This is done a) for reasons of simplicity and b) because the described depth-damage relationship with highest damage increases for low inundation depths seems to be plausible also for other damage categories in cities. Using Eq. (3) the urban flood risk is computed:

$D=\frac{27 \sqrt{h_{w}}}{100}$

$R=\sum_{i=1}^{k} 0.5 D\left(P_{i-1}\right)+D\left(P_{i}\right)\left|P_{i}-P_{i-1}\right|$

where $R$ is the risk of a cell $i, D$ is the damage at water level $h_{w}$ and $P$ is the probability of the flood event.
After standardising the different risk values between 0 and 1 , the aggregation of single risk maps to a multicriteria risk map is carried out, calculating different criteria sets by an additive weighting approach (Eq. 4):

$X_{i}=\sum_{b} w_{b} x_{i b}$

In doing so, the standardised value of a grid cell $x_{i b}$ is multiplied by its weight $w_{b}$. For each grid cell the weighted risk values are added to an overall risk value $X_{i}$. The sum of the weights for each criteria set adds up to $100 \%\left(\sum w_{b}=1\right)$ where 1 represents a high risk and 0 a low risk.

The weighting of the single criterion in the criteria sets we applied is given in Table 3: we set up a so-defined EQUAL criteria set where all three dimensions of flood vulnerability are equally weigthed (33.3\% or $w=0.3$; Table 3 ). An addition to this, we use an ECON and a SOCIAL set to include two options where we put more weight on human life and value assets at risk - as the economic and social departments of the city of Leipzig would probably define their scenarios here, the economic and social criteria account for a weight $w$ of 0.6. Respectively, we also set up an ecological scenario, ECOL, where $60 \%$ of the weights are assigned to the ecological dimension. Since we argued that human lives are the most important goods to protect in a city we also formulated two social hot spot criteria weightings such as for the social hot 
spots SPOTS where $90 \%$ of all weights are assigned to social hot spots and COHORTS which assigns $90 \%$ of all weights to the most vulnerable age classes introduced in Sect. 3.1. In addition, we ran an "extreme" economic-oriented scenario where $90 \%$ of all weights are assigned to the economic risk and the land value and, finally, an "extreme" ecological scenario where $90 \%$ of all weights are given to the ecological dimension.

\section{Results and discussion}

\subsection{Flood damage maps}

Considering more frequent floods (1/50) with a limited spatial inundation extent, economic damage is restricted to allotment gardens, sport and recreation areas in the northern and southern floodplains of the city (8\% of the city area). These areas have medium to low damage values. By comparison, floods with low recurrence probabilities but covering larger areas and with high inundation levels $(\geq 1 / 100)$ will cause considerable damage to housing areas, the transport infrastructure, industrial and commercial areas in the inner part of the city (Fig. 4) adjacent to the northern and southern floodplains which boast the majority of the old built-up housing estates from the Wilhelminian Period that belong to the most densly populated and highly valued residential areas of Leipzig. Overall, in case of an extreme flood, about $15 \%$ of the city - that is $45 \mathrm{~km}^{2}$ - would be flooded.

Figure 4 also provides evidence that the main transport node of railway and public transport - the main train station of Leipzig - would be substantially affected by a $\geq 100$ year flood if no additional technical flood protection measures are considered. When aggregating the economic, ecological and social risk for each flood recurrence interval we find a logarithmic curve for both the economic and the ecological risks and an exponential increase in the number of raster cells where social hot spots such as hospitals, residential homes for the elderly, kindergartens and schools are situated. This underlines the fact that social data should not be omitted when evaluating the urban flood risk.

\subsection{Flood risk maps}

For each of the three dimensions of vulnerability a separate risk map was computed (Figs. 5-7). As the damage maps show, most of the areas with a low (values from 0.1 to 0.5 ) or moderate to high economic risk (values from 0.5 to 1.0) are located in the northern, northeastern and southern floodplainprone parts of the city (Fig. 5). High risk areas (up to 1.0) are to be found along the small river Parthe in the eastern residential part of the town although these only cover a small proportion.

With regard to the social risk, the municipal districts close to the floodplains in the southern part of the city, which belong to the afore-mentioned residential areas from the
Wilheminian Period, are densily populated with an aboveaverage proportion of families with young children. In the emergency event of $a \geq 100$-year flood they would be in danger of being trapped in their houses and cut off from the public transport, social and shopping infrastructures as well as from (emergency) health care.

Compared to the distribution of the economic risk, the social hot spots of flood risk are located in the central part of the floodplains and floodplain-adjacent areas (Fig. 6). It is here that mostly residential areas are situated. Whereas the distribution of elements of risk is almost equally distributed over the entire areas given in Fig. 6, moderate to high risk values were only calculated for selected sites where there is a concentration of vulnerable groups (social infrastructure places) such as small children or elderly people who are expected to require personal assistance in the event of a flood.

Looking at Fig. 7 which shows the distribution of the ecological risk values we see that the areas of ecological risk are to a large extent also located in the central and southern parts of the floodplains although complementary to those discussed for the social risk. They cover the uninhabited parts of the floodplains and the risks predominantly arise from either damages to recreation areas (parks, paths, fallen trees) or the probability of releasing pollutants at urban brownfields and contaminated sites in the floodplains (waste disposal, fertilised gardens, sewage treatment plants, etc.). Most of the ecological risks were found to be low (values from 0.1-0.3).

A specific but nonetheless important ecological risk for urban nature results from an increase in non-floodplain tree species such as Acer platanoides into the floodplain forests of Leipzig over the last 150 years. Nowadays, marpledominated tree stands account for up to $45 \%$ in selected parts of the forests (Haase and Gläser, 2009). These trees are not adapted to longer periods of inundation and die-off after a short period of flooding (Hauschild and Hein, 2008), which causes additional clearing work for the urban department of forestry and additional costs.

\subsection{Multicriteria flood risk maps and weighting}

The spatial patterns of urban flood risk for all three dimensions of vulnerability are partly overlapping and complementary. Computing the aggregated flood risk of a city means that all of these dimensions have to be considered. The weighting approach used enables the sensitivity of the risk mapping results to be displayed against different sets of priorities or weights that urban experts such as planner or risk managers might have (Kienberger et al., 2009). In Figs. 8 and 9, we compare the aggregated risk value distribution of the same area shown in Figs. 5-7 for different weight sets. In the EQUAL criteria set, equal weights of $33 \%$ were given to the three dimensions of vulnerability - economic, social and ecological (Fig. 8). In the ECOL criteria set, a large weight of 0.6 was given to the ecological criteria (Fig. 9). Although the spatial pattern of the risk values among the three criteria 

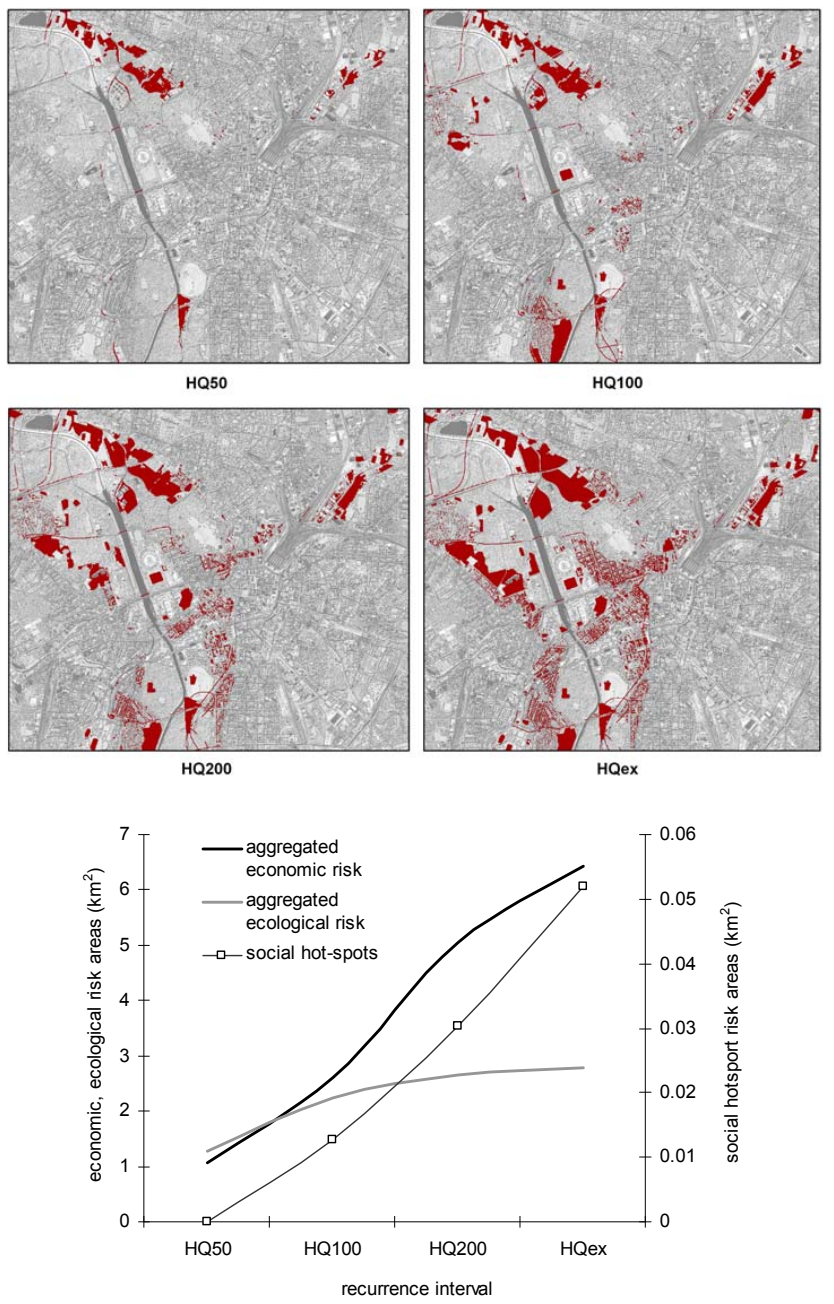

Fig. 4. Areas where economic damages will occur due to an inundation of different recurrence intervals: 50, 100, 200-year and extreme flood.

sets differ, both of the latter weight sets show a wide spread of cells with very low risk values $\left(X_{i}=0.001 \ldots 0.1\right)$. In the event of a higher flooding probability, high risk values can be found in the northern and southern floodplain-prone areas for all computed criteria sets. In the EQUAL criteria set, large areas in the southern and northern flood plains have risk values of $0.1 \ldots 0.2$. By contrast, the ECOL criteria set has a further subdominant peak in the value area of $0.3 \ldots 0.4$ for the same areas. Accordingly, the choice of weights can be used to express different opinions but also conflicts of interest within a planning and decision-making process for flood risk management. Thus, it can also be implemented for the communication of risk.

In Table 4, we compare the number of cells "at risk" from all of the different criteria sets computed. The EQUAL criteria set (cf. Sect. 3.4) is used as a reference criteria set. We classified the range of risk values $0 \ldots 1$ into three classes: high values $(0.5 \ldots 1)$, medium values $(0.1 \ldots 0.5)$ and low values $(0.001 \ldots 0.1)$. When compared with the EQUAL criteria set, $50 \%$ of the other criteria sets exceed the number of cells at risk computed for EQUAL. The criteria sets focussing on specific cohorts "COHORTS", and the social hot spots 'SPOTS' show a considerably higher number of areas with high flood risk. Conversely, the economic and social criteria sets "ECON" and "SOCIAL" turned out to have more medium and low risk values compared to the reference criteria set. Both extreme sets, the economic and the ecological one, where $90 \%$ of the weights were either assigned to the economic or the ecological criteria show higher risk values compared to the criteria set "EQUAL". This illustrates that the weighting of the risk criteria is just as important as the previously differentiated calculation as differently weighted criteria sets alter both the value and spatial distribution of the total flood risk in a city area.

\subsection{Potentials and limitations of the method adaptation}

Coming back to the three research questions that were asked in the introduction of the paper, first and foremost it can be stated that the adaptation of the multicriteria flood risk procedure developed by Meyer et al. (2009a, b) for the Mulde river basin to a city was successful. The set of flood risk criteria used by Meyer et al. (2009a, b), was adopted, enhanced and optimised for an urban area. Thereby the hierarchical approach of criteria, sub-criteria and elements of risk was a very useful base to include the multitude of variables determining urban flood risk and vulnerability comprehensively. The enhancement of the criteria set includes mainly economic and social elements of risk as these are characteristic for cities. However, particularly in terms of housing costs and purchasing power of the residents/households additional detailed data for the economic dimension of urban flood risk would be important when further developing the presented approach. But such data are firstly, often not available beyond the municipal district level and, secondly, collected by private firms and thus expansive (Meyer, 2005). Moreover, also the social and ecological criteria were difficult to determine beyond the municipal district level due to missing spatially explicit quantitative data (at which the regular urban statistics and census works).

For some criteria, an inundation-depth-damagecalculation function was applied. For all binary-displayed criteria, a detailed level of potential damage was not considered. This loss of accuracy was consciously accepted: In contrast to common methods, which try to calculate direct damage accurately (King, 2001; Meyer, 2005), the introduced approach aimed at assessing a broad range of different risks including all three dimensions of flood risk. By assigning multiple risk values to each cell it is possible to identify areas of differentiated and multi-facetted flood risk which is a better base to establish different mitigation measures in a city. However, the damage valuation by use of inundation-depth-damage-functions still involves 

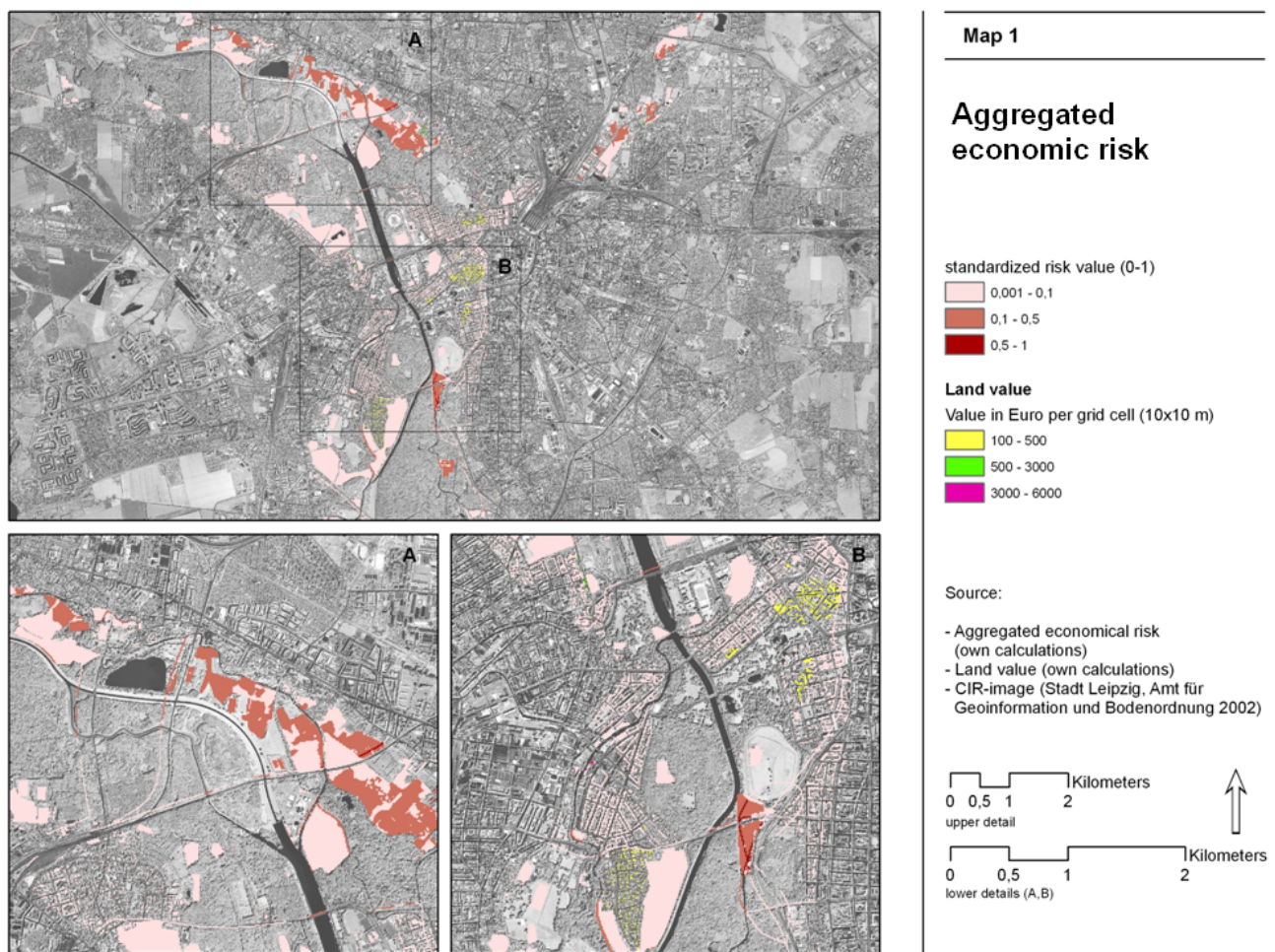

Fig. 5. GIS-map displaying the aggregated economic risk standardised between 0 and 1 and the land value (in $€$ ).
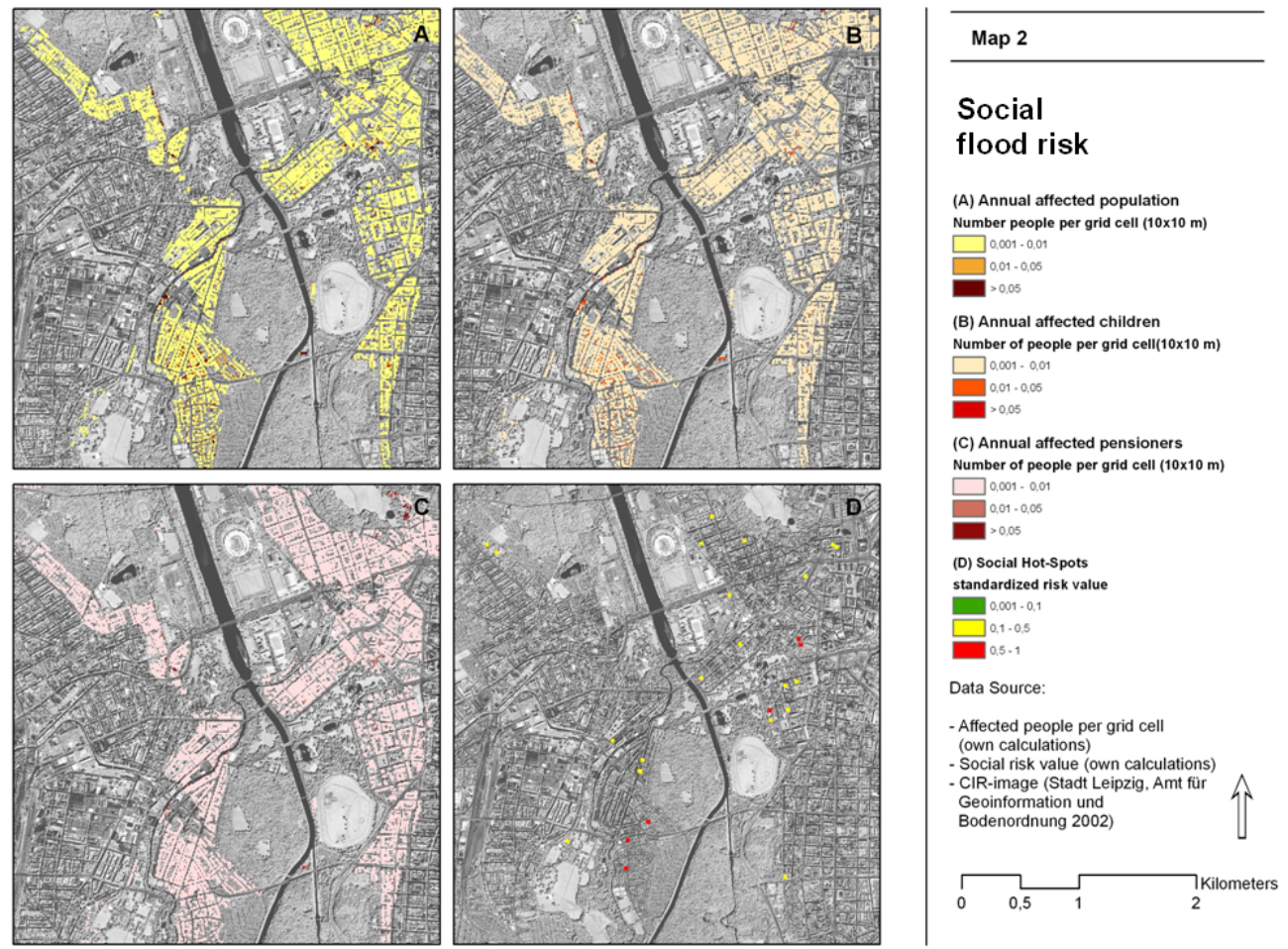

Fig. 6. GIS-map displaying the aggregated social risk standardised between 0 and 1 , the annual affected population, the annual number of affected children and elderly people. 

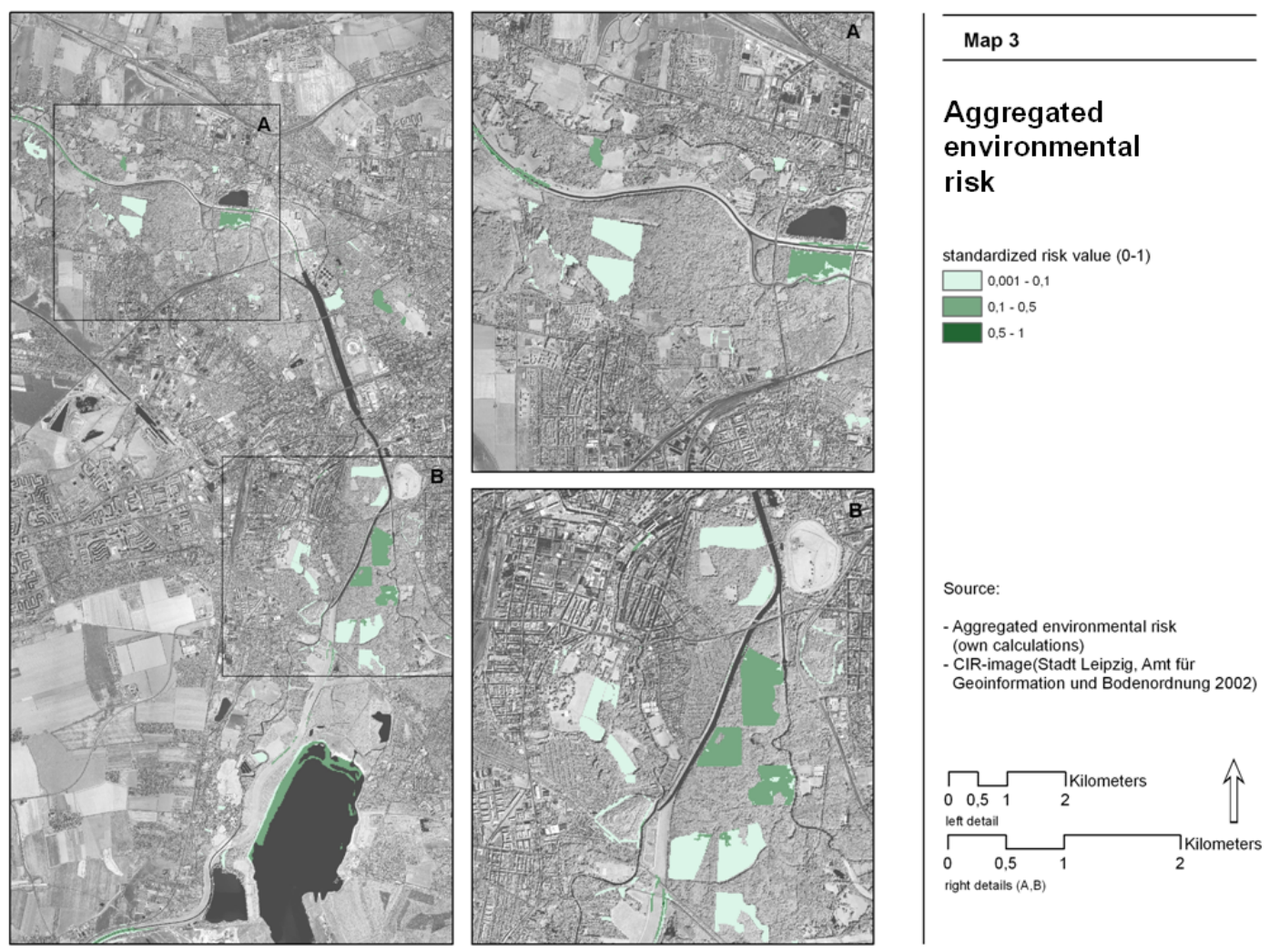

Fig. 7. GIS-map displaying the aggregated ecological risk standardised between 0 and 1.

Table 4. Risk value distribution for each of the computed criteria sets. The arrows compare the respective set with the reference criteria set EQUAL where all three criteria are equally weighted.

\begin{tabular}{|c|c|c|c|c|c|c|c|c|c|}
\hline & & EQUAL & ECON & SOCIAL & ECOL & SPOTS & COHORTS & $\begin{array}{l}\text { ECON } \\
\text { extrem }\end{array}$ & $\begin{array}{l}\text { ECOL } \\
\text { extrem }\end{array}$ \\
\hline \multirow{3}{*}{ 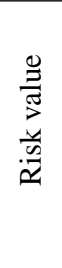 } & $\begin{array}{l}\text { high values } \\
(0.5-1.0)\end{array}$ & $0^{*}$ & - & - & $\uparrow$ & $\uparrow$ & $\uparrow$ & $\uparrow$ & $\uparrow$ \\
\hline & $\begin{array}{l}\text { medium values } \\
(0.1-0.5)\end{array}$ & 12.968 & $\uparrow$ & $\uparrow$ & $\downarrow$ & $\downarrow$ & $\downarrow$ & $\downarrow$ & $\downarrow$ \\
\hline & $\begin{array}{l}\text { low values } \\
(0.001-0.1)\end{array}$ & 44.845 & $\uparrow$ & $\uparrow$ & $\downarrow$ & $\downarrow$ & $\downarrow$ & $\uparrow$ & $\downarrow$ \\
\hline
\end{tabular}

* Number of cells.

considerable uncertainties (Merz et al., 2004) as it is - firstly - not adapted to the specific city on interest and, secondly, because the values in cities constantly change (mostly rise; Maantay and Maroko, 2009). Additionally, assigning a value to human life is difficult, if not impossible, and might involve serious moral conflicts (as discussed/mentioned in e.g. Ebert et al., 2009; Cutter et al., 2003; King, 2001). However, in order to represent the factor of human life and health in the risk assessment we kept the criteria of number and age of the urban population in the approach. Thus, the weighting approach of the urban flood risk criteria provided comprehensive spatially differentiated flood risk maps which can show the spatial hot spots of flood risk in Leipzig.

\subsection{Spatial disparities, scale and risk bundles in cities}

There are still challenges to improve the procedure presented in this study which will be briefly discussed in this final section: a scale of 1:25000 to 1:10000 and socio-economic data for local municipal districts as we used in this paper always 

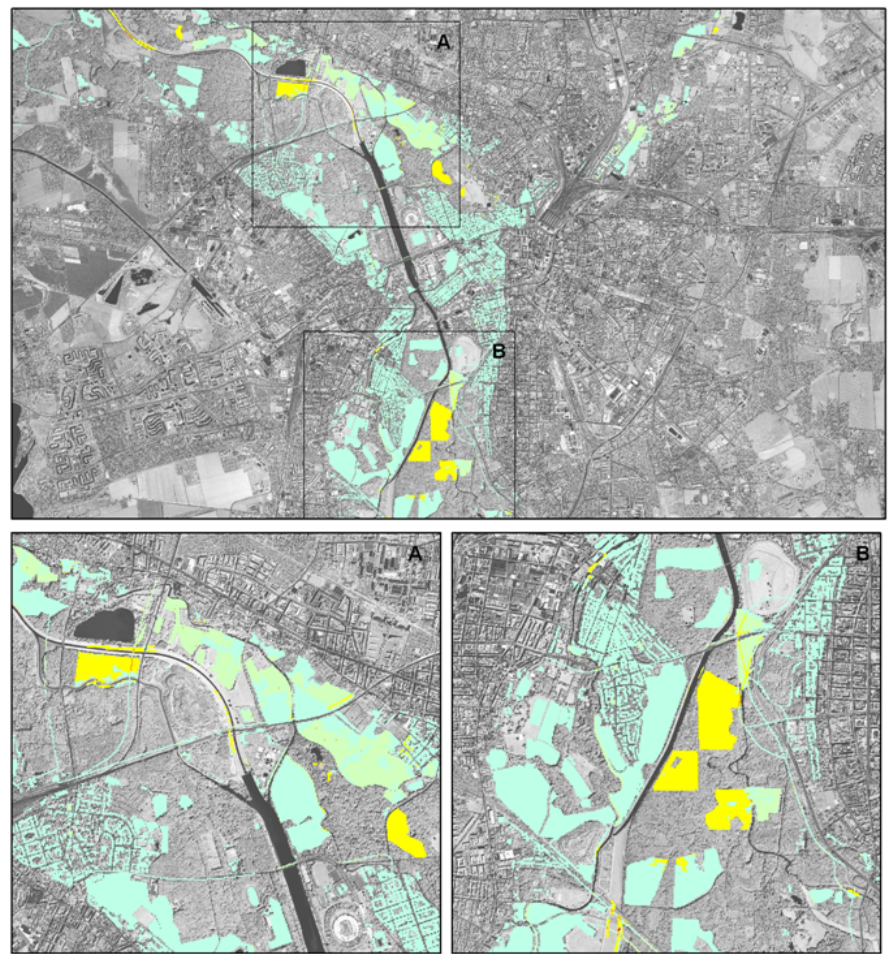

\section{Map 4 \\ Aggregated flood risk map}

Scenario EQUAL

Risk value (standardized)

$\square 0,001-0,05$

$0,05 \cdot 0,1$

$0,1 \cdot 0,2$

$0,2 \cdot 0,3$

$0,3 \cdot 0,4$

$0,4 \cdot 0,5$

$0,5-1$

Source:

- Risik value (own calculations)

Geoinformation und Bodenordnung 2002)

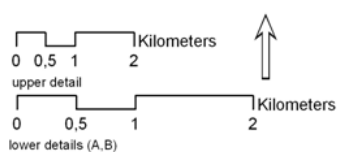

lower details $(A, B)$

Fig. 8. Aggregated multicriteria flood risk map: the EQUAL criteria set displayed gives equal weighting to the aggregated social, economic and ecological risk (0.33 each).

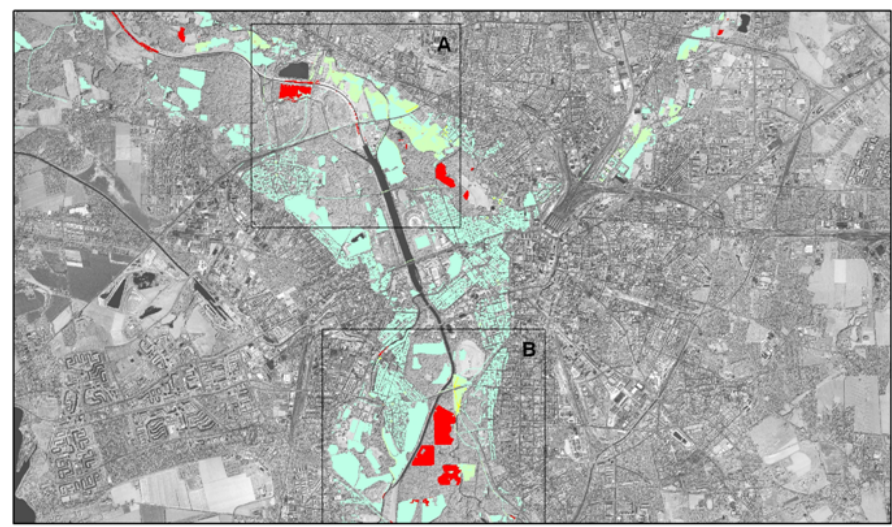

\section{Map 5 \\ Aggregated flood risk map}

Scenario ECOL
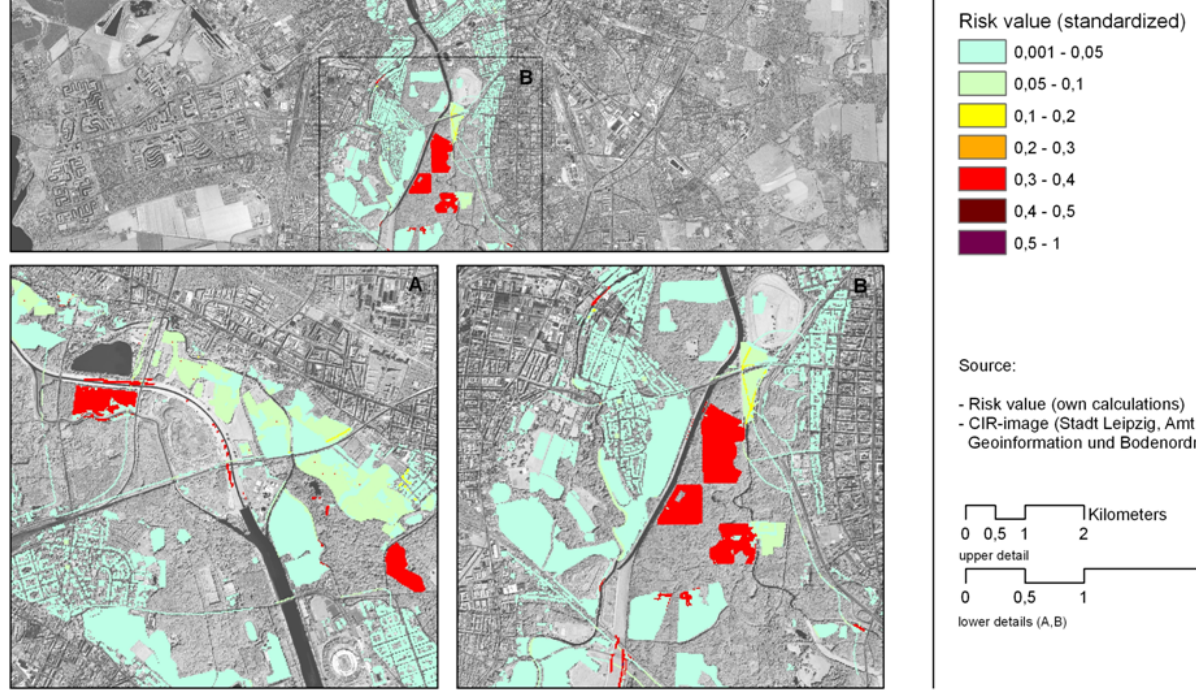

Source:

Risk value (own calculations)

Geoinformation und Bodenordnung 2002)

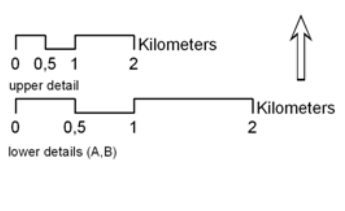

Fig. 9. Aggregated multicriteria flood risk map: the ECOL criteria set displayed gives most weighting to ecological criteria (60\%) and less to social $(20 \%)$ and economic ones $(20 \%)$. 
aggregate data which only partly provides satisfying information on the block, house or even individual household level. Heterogeneities in the distribution of the urban population, household patterns, densities and properties of the built-up environment could not be acknowledged in our analysis so far. Also detailed data of housing costs, household income and household purchasing power were not available.

However, it is precisely these characteristics that are of decisive importance when developing risk mitigation and adaptation measures and plans in order to reduce flood risk. From an implementation point of view, the enhanced software package of FloodCalc Urban is able to run such finegrain data models for selected areas. Hence, future activities will a.o. focus on compiling a fine-grain urban database to overcome this major bottleneck of data (non-)availability.

In accordance with Meyer et al. (2009a, b), for the city of Leipzig we found many spatial disparities from risk mapping. However, this pure identification of high risk areas does not yet answer the question on the extent and way in which this risk could or should be reduced and how risk reduction efforts can be distributed "fairly" across a city (Johnson et al., 2007) as our EQUAL criteria set for example suggests.

\section{Conclusions}

The results of our study show by evidence that better knowledge of the spatial distribution of social, economic and ecological elements of risk can help to develop "bundles" of criteria or elements of risk that refer to a specific risk situation (of a group or of an area) and thus go far beyond the criticized dominant technocratic approach to hazards analysis (Haque and Erkin, 2007). Since it is not the entire city that is affected by flooding, even in the worst case of an extreme flood, based on our flood risk mapping we can show exactly where the flood hazard makes urban residents vulnerable due to their socio-economic or demographic situation.

However, in our approach, social science knowledge of individual vulnerabilities and risk perception as investigated by Kuhlicke and Steinführer (2006) are still missing for the urban context. For example an integration of the individual or household-based accessibility to emergency points and public transport facilities of the most vulnerable social groups would be of particular importance. In addition, for household types it should be possible to develop some kind of "profiles of coping capacity" that include educational background, information access, financial limitations and so forth. The same is relevant for the different urban housing types that differ far more than simply in terms of their floor numbers. The chosen criteria to define the urban flood risk are, however, a good starting point to proceed in a direction of more context-based urban flood risk assessment.

Acknowledgements. We would like to thank Nadja Kabisch and Martin Volk for their very useful comments on an earlier version of this manuscript. Parts of this work were supported by the
EU Integrated Projects PLUREL (contract number 036921) and FLOODsite (contract number GOCE-CT-2004-505420).

Edited by: K.-T. Chang

Reviewed by: D. Yu and another anonymous referee

\section{References}

Apel, H., Thieken, A. H., Merz, B., and Blöschl, G.: Flood risk assessment and associated uncertainty, Nat. Hazards Earth Syst. Sci., 4, 295-308, 2004, http://www.nat-hazards-earth-syst-sci.net/4/295/2004/.

Blaikie, P., Cannon, T., Davis, I., and Wisner, B. (Eds.): At risk: Natural hazards, people's vulnerability, and disasters, Routledge, London, UK, 1994.

Bronstert, A.: River flooding in Germany: influenced by climate change?, Phys. Chem. Earth, 20, 445-450, 1996.

Brouwer, R. and van Ek, R.: Integrated ecological, economic and social impact assessment of alternative flood control policies in the Netherlands, Ecol. Econ., 50(1-2), 1-21, 2004.

City of Leipzig: Municipal monitoring report on the urban environment, issued by: Urban Planning Department in cooperation with the Municipal Environmental Agency, 2008.

Cutter, S. L., Boroff, B. J., and Shirley, W. L.: Social Vulnerability to Environmental Hazards, Soc. Sci. Quart., 84(2), 242-261, 2003.

Davidson, C.: Was 2005 the year of natural disasters?, B. World Health Organ, 84, 4-8, 2006.

de Moel, H., van Alphen, J., and Aerts, J. C. J. H.: Flood maps in Europe - methods, availability and use, Nat. Hazards Earth Syst. Sci., 9, 289-301, 2009,

http://www.nat-hazards-earth-syst-sci.net/9/289/2009/.

Ebert, A., Kerle, N., and Stein, A.: Urban social vulnerability assessment with physical proxies and spatial metrics derived from air- and spaceborne imagery and GIS data, Nat. Hazards. 48, 275-294, 2009.

Enke, W. and Küchler, W.: Zusammenfassender Bericht zur Klimaprognose für Sachsen, Freie Universität Berlin, Institut für Meteorologie, 3-19, 2000..

Fekete, A.: Validation of a social vulnerability index in context to river-floods in Germany, Nat. Hazards Earth Syst. Sci., 9, 393403, 2009, http://www.nat-hazards-earth-syst-sci.net/9/393/2009/.

Filatova, T., Parker, D., and van der Veen, A.: Agent-Based Urban Land Markets: Agent's Pricing Behavior, Land Prices and Urban Land Use Change, JASSS, 12(1), 3 pp., 2009.

Flood Directive 2007/60/EC on the assessment and management of flood risks, available at: http://ec.europa.eu/environment/water/ flood\{_\}risk/index.htm, last access: 11 August 2009.

Gouldby, B. and Samuels, P.: Language of risk - project definitions, Floodsite project report T32-04-01, 2005.

Gruenewald, U.: Überschwemmungen, in: Naturkatastrophen. Ursachen - Auswirkungen - Vorsorge, edited by: Plate, E. J. and Merz, B., Schweizerbart'Sche Verlagsbuchhandlung, Stuttgart, 159-189, 2001.

Haase, D. and Gläser, J.: Determinants of floodplain forest development illustrated by the example of the floodplain forest in the District of Leipzig, Forest Ecol, Manag., 258, 887-894, 2009. 
Haque, C. and Etkin, D.: People and community as constituent parts of hazards: the significance of societal dimensions in hazards analysis, Nat. Hazards, 41, 271-282, 2007.

Hauschild, R. and Hein, S.: Zur Hochwassertoleranz von Laubbäumen nach einem extremen Überflutungsereignis - Eine Fallstudie aus der südlichen Oberrheinaue, Allg. Forst- u. J.-Ztg., 180(5/6), 100-109, 2008.

HOWAS - the web-based flood information system of Germany, Helmholtz-Zentrum Potsdam, Deutsches GeoForschungsZentrum GFZ, available at: http://nadine-ws.gfz-potsdam.de:8080/ howasPortal/client/start, last access: 10 August 2009.

Johnson, C., Penning-Rowsell, E., and Parker, D.: Natural and imposed injustices: the challenges in implementing "fair" flood risk management policy in England, Geogr. J., 173(4), 374-390, 2007.

Kaplan, M., Renaud, F. G., and Lüchters, G.: Vulnerability assessment and protective effects of coastal vegetation during the 2004 Tsunami in Sri Lanka, Nat. Hazards Earth Syst. Sci., 9, 14791494, 2009, http://www.nat-hazards-earth-syst-sci.net/9/1479/2009/.

Kienberger, S., Lang, S., and Zeil, P.: Spatial vulnerability units expert-based spatial modelling of socio-economic vulnerability in the Salzach catchment, Austria, Nat. Hazards Earth Syst. Sci., 9, 767-778, 2009,

http://www.nat-hazards-earth-syst-sci.net/9/767/2009/.

King, D.: Uses and Limitations of Socioeconomic Indicators of Community Vulnerability to Natural Hazards: Data and Disasters in Northern Australia, Nat. Hazards, 24, 147-156, 2001.

King, D. and MacGregor, C.: Using social indicators to measure community vulnerability to natural hazards, Australian Journal of Emergency Management, 15, 52-57, 2000.

Krüger, F., Meissner, R., Gröngröft, A., and Grunewald, K.: Flood induced heavy metal and arsenic contamination of Elbe river floodplain soils, Acta Hydroch. Hydrob., 33, 455-465, 2005.

Krysanova, V., Buiteveld, H., Haase, D., Hattermann, F. F., Van Niekerk, K., Roest, K., Martínez-Santos, P., and Schlüter, M.: Practices and Lessons Learned in Coping with Climatic Hazards at the River-Basin Scale: Floods and Droughts, Ecol. Soc., 13(2), 32 pp., 2008.

Kuhlicke, C. and Steinführer, A.: Wie vorbereitet ist die Bevölkerung auf ein Hochwasserrisikomanagement? Lehren aus dem Hochwasser 2002, in: Strategien und Instrumente zur Verbesserung des vorbeugenden Hochwasserschutzes, edited by: Jüpner, R., Shaker, Aachen, Magdeburger Wasserwirtschaftliche Hefte 6, 45-55, 2006.

Kundzewicz, Z. W. and Kaczmarek, Z.: Coping with hydrological extremes, Water Int., 25(1), 66-75, 2000.

Maantay, J. and Maroko, A.: Mapping urban risk: Flood hazards, race, \& environmental justice in New York, Appl. Geogr., 29, 111-124, 2009.
Meyer, V.: Methoden der Sturmflut-Schadenspotenzialanalyse an der deutschen Nordseeküste, Vom Fachbereich Geowissenschaften und Geographie der Universität Hannover genehmigte Dissertation, UFZ dissertation 3/2005.

Meyer, V., Scheuer, S., and Haase, D.: A multi-criteria approach for flood risk mapping exemplified at the Mulde river, Germany, Nat. Hazards, 48, 17-39, 2009a.

Meyer, V., Haase, D., and Scheuer, S.: Flood Risk Assessment in European River Basins - Concept, Methods and Challenges, Integrated Environmental Assessment and Management, 5(1), 1726, 2009b.

Milly, P. C. D. , Wetherald, R. T., Dunne, K. A., and Delworth, T. L.: Increasing risk of great floods in a changing climate, Nature 415, 514-517, 2002.

Neumeister, H., Krüger, A., and Schneider, B.: Problems of artifical flooding of flood plain forests in an indutrial region in Germany, Global Ecol. Biogeogr., 6, 197-209, 1997.

Pelling, M.: The vulnerability of cities. Natural disasters and social resilience, London, 2003.

Schanze, J.: Flood risk management - a basic framework, in: Flood Risk Management - Hazards, Vulnerability and Mitigation Measures, edited by: Schanze, J., Zeman, E., and Marsalek, J., Springer, 149-167, 2006.

Schätzl, L.: Theorie, Paderborn, UTB Geographie, Wirtschaftswissenschaften, 782 pp., 2003.

Simonovic, S. P. and Nirupama, N.: A spatial multi-objective decision-making under uncertainty for water resources management, J. Hydroinform., 7(2), 117-133, 2005.

Steinhardt, U. and Volk, M.: The investigation of water and matter balance on the meso-landscape scale: A hierarchical approach for landscape research, Landscape. Ecol., 1, 1-12, 2002.

Tapsell, S. M., Penning-Rowsell, E., Tunstall, S. M., and Wilson, T. L.: Vulnerability to flooding: health and social dimensions, Philos. T. R. Soc. Lond., 360, 1511-1525, 2002.

Thinh, N. X. and Vogel, R.: GIS-based multiple criteria analysis for land-use suitability assessment in the context of flood risk management, InterCarto - InterGIS 12, Berlin, 2006.

Tkach, R. J. and Simonovic, S. P.: A new approach to multi-criteria decision making in water resources, Journal of Geographic Information and Decision Analysis, 1(1), 25-43, 1997.

US EPA: Framework for Ecological Risk Assessment, Risk Assessment Forum, US Environmental Protection Agency, Washington, DC, EPA 630/R-92/001, 1992.

WBGU (Wissenschaftlicher Beirat der Bundesregierung, Globale Umweltver-änderungen): Welt im Wandel: Strategien zur Bewältigung globaler Umweltrisiken. Jahresgutachten 1998, Berlin, 1999. 